\title{
Is It Formal or Informal? Choice of Market Outlets for Unprocessed Tea in Nandi County, Kenya
}

\author{
Mr. Vincent Mittei \\ Department of Agricultural Economics and Agribusiness Management, Egerton University \\ Dr. Hillary Bett \\ Department of Agricultural Economics and Agribusiness Management, Egerton University \\ Dr. Jackson Langat \\ Tegemeo Institute of Agricultural Policy, Egerton University
}

\begin{abstract}
The tea industry plays a key role in the agriculture sector and the economy at large with tea output contributing about $11 \%$ of the agriculture sector's contribution to Gross Domestic Product. Like many other crops in Kenya, tea is produced both on small and large-scale basis. Smallholder farmers in Kenya make a significant contribution to the industry producing $61 \%$ of the total national production and with $66 \%$ of tea acreage. Formal market outlets are more profitable than informal ones. However, small tea agri enterprises in Nandi County prefer selling their unprocessed tea to informal market outlets. Empirical evidence on what motivates these agrienterprises to sell most of their tea to these outlets is scanty. The main objective of this study was to compare the profitability of formal and informal market outlets for unprocessed tea in Nandi County. Multistage sampling procedure was employed and 384 respondents interviewed using semi-structured questionnaire. Data were analysed using gross margin analysis. Formal market outlets are more beneficial because of higher gross margin rate of $12.71 \%$ compared to informal market outlets having the gross margin rate of $1.08 \%$. The findings are helpful in guiding smallholder tea farmers in information on the most profitable and efficient market outlets and informing policy makers on how to improve the efficiency of market outlets.
\end{abstract}

DOI: $10.7176 / \mathrm{JESD} / 11-22-10$

Publication date: November $30^{\text {th }} 2020$

\section{INTRODUCTION}

Kenya has a dual economy comprising of formal and informal economy. It is also an agricultural based economy with leading crops being tea, horticulture, cereals (wheat and maize), sugarcane and livestock production contributing to rural employment, food production, foreign exchange earnings and rural incomes (Kiprono et al., 2011). The agricultural sector directly accounts for about 26 per cent of Kenya's Gross Domestic Product (GDP) and 27 per cent indirectly through linkages with manufacturing, distribution and other service related sectors (KNBS, 2016).

Entrepreneurial and market orientation, as well as organizational competency and the ability to use social networks, are important capacities upon which famers can build competitive advantages to help them succeed in free markets and eventually achieve sustainable development (McElwee, 2006).Competitive advantages mediate entrepreneurial orientation and marketing performance reflected from the innovation and market differentiation (Pardi, 2014).

Market liberalization has given farmers a choice of where to sell their unprocessed tea. The multinational firms have at least managed to access the smallholder tea farmers, which were not possible before market liberalization. The freedom of market choice has led to rise of whether formality or informality in marketing. Informal markets outlets is being preferred by majority of farmers because they pay promptly for the unprocessed tea delivered as per demands of the farmer while KTDA and private companies pays on monthly basis (Kirui et al., 2014). Informal market outlets are evident as one of the main arising market alternatives in the tea industry. Trends in industry provide a platform for emergence of unregulated businesses. In this case, liberalization of the tea sector is the key factor that influence the behaviour and production techniques of smallholder tea farmers in Kenya. Increased awareness on entrepreneurial and market orientation have had greater impact on the welfare of the household through change in production levels and income from tea agrienterprises. Informal market outlets involves agri-preneur trading tea leaves among themselves (Muku and Mwaura, 2007).

The choice of market outlet is the farmers' decision-making behaviour and market orientation on where to sell their farm produce. Marketing outlet choice is determine by numerous factors that include socio-economic factors, institutional factors, production factors and market factors. These factors could have negative or positive influence, which could eventually affect the welfare of the smallholder farmers. 


\section{LITERATURE REVIEW}

Formal economy is defined as economic zone that is legally sanctioned, regulated through state intervention, and marked by regular work. In contrast, the informal economy is defined as irregular work, outside legal sanction, without state regulation (Yusuff, 2011). According to Obare (2015), government policy approach to informal economy in Kenya is not popular among the economy investors. This approach has significantly compromise informal employment creation for the majority formally unemployed citizens. However, Africa Development Bank (AFDB, 2013) report indicate that despite the informal economy contributing about 55 per cent of SubSaharan Africa's GDP and 80 per cent of the labour force, most government and affiliated agencies pay little attention to the role of informal economy in fostering growth and creating jobs.

The informal economy thrives in a context of high unemployment, underemployment, poverty, gender inequality and precarious work (ILO, 2014). This is in line with SIDA's major concern areas of activities. Informal activities play significant role income generation, because of the relative ease of entry and low requirements for education, skills, technology and capital. However, most people enter the informal economy not by choice, but out of a need to survive and to have access to basic income-generating activities. According to SIDA (2004) report, there should be increased the knowledge of the informal economy within the organization in order to address the problems at hand (Becker, 2004; ILO, 2014).

Tea has remained dominant in contributing to household income in growing areas. Most farmers have less awareness in importance of diversifying to other enterprises. Mwaura et al. (2010) observed that development agencies have neglected smallholder tea farmers have been by with assumption that tea is a leading export crop and thus high levels of poverty. This is in contrast with one of five elements of poverty reduction strategies indicated in the Kenya Economic Report (2013). These strategies requires that the productivity of smallholder farms need to be enhanced since majority of Kenya's poor depend on smallholder agriculture for their livelihood, increasing their productivity through the use of fertilizer, improved seeds and access to markets, will lead to significant poverty reduction in the short to medium term. The report indicates that based on Kenya's national poverty line, close to half of the population (close to 17 million Kenyans) was poor in 2005 and the vast majority of the poor lived in rural areas. Poor households are also more likely to depend on income and consumption from crops and livestock, as a source of livelihood (Karimi, 2008).

Idea behind establishment of net welfare was assumption that tea farming household whose returns from tea enterprise were less than its financial requirement to meet basic needs were consider poor. The basis for household financial requirements is on the number of adult equivalent and the cost of buying basket of necessities. According to them, they measure the welfare level as net of return from tea enterprise less the household costs on necessities (Mwaura and Muku, 2007). However, investments in both farm and non-farm diversification could increase the production and income. Therefore, encouraging public and private investment in education will help in rural economy diversification (Joshi, 2004).

Tea farming is one of the major income earner among smallholder farmers in rural describe how tea farming leads in generating income for those who have multiple enterprises. Furthermore, literature indicates that one out of five farmers had off farm activities that supplement tea income. This therefore concludes that majority of them depend on tea enterprise as the main income generating enterprise having increased earning contributed by liberalization of the sector. It has also helped farmers improve motivation and satisfaction (Mwaura et al., 2010; Keraro et al., 2012). According to Kirui et al. (2014), government has also benefited from the liberalized tea sector as source of revenue by way of corporation tax. Furthermore, it has given farmers full responsibilities of their farms and factories, which was way back government work. This shows that government has less to worry about the efficiency and management of value chain.

\section{MATERIALS AND METHODS}

3.1 Study area, sampling, and data: The study covered Chesumei Sub-County occupies a part of $472.10 \mathrm{Km}^{2}$ with a population of 130,752 individuals and is lined by Mosop Sub-County to the north and Emgwen SubCounty to the south. It is divided into 5 wards namely; Chemundu/Kapng'etuny, Kaptel/Kamoiywo, Kiptuiya, Kosirai, Ngechek/Lelmokwo). Geographically, Nandi County is bound by the Equator to the south and extends northwards to latitude $0^{\circ} 34^{\prime} \mathrm{N}$. The Western boundary extends to Longitude $34^{\circ} 45^{\prime} \mathrm{E}$, while the Eastern boundary reaches longitude $35^{\circ} 25^{\prime} \mathrm{E}$ (CIDP, 2013).

Generally, Chesumei Sub County receives an average rainfall of about $1200 \mathrm{~mm}$ to $2000 \mathrm{~mm}$ per annum. The long rains begin in early March and continue up to end of June whereas short rains begin in September and end in November. Only rarely is there a month without some rainfall. The dry spell is usually experience from end of December to mid-March. Crop and livestock production is the main source of livelihood. Most parts of the County experience mean temperatures between $20^{\circ} \mathrm{C}$ during the rainy season. During the dry months of December and January the temperatures are as high as $23^{\circ} \mathrm{C}$ and during the cold spell of July and August the night temperatures are as low as $14^{\circ} \mathrm{C}(\mathrm{CIDP}, 2013)$. 
Chesumei Sub-County was purposively selected because it is the tea catchment area for both KTDA (Chebut tea factory) and private companies. Presence of formal and informal market outlets for unprocessed tea will enable comparison between the two outlets. Tea agri-enterprises are opting for informal market outlets though there is an established formal market outlet and therefore there is need to examine why they are shifting or what drive them.

A sample of 384respondents was selected from a population of smallholder tea farmers in Chesumei Sub County. Out of the five administrative wards in the Sub-County, two wards were purposively selected; Kaptel and Chemundu. Primary data was collected through interviews, using a semi-structured questionnaire during the months between October to November 2019

\subsection{Model specification;}

Gross margin analysis was used to compare profitability of two market outlets available for farmers. The model was preferred because it provides an easy way to understand profitability of an enterprise as it shows how effective management can bring profits from sales and how an enterprise can minimize competition (McClure, 2004). The GMA model is very useful in cases where some data, for example analyzing the profit of an enterprise. However, the calculation of depreciation has often been difficult to undertake due to the ambiguity related to nature of estimating the lifespan of fixed assets, appreciation, and salvage value in many firms, thus necessitating the use of GMA models rather than the normal profit margin models.

Gross margin refers to the entire financial gain derived from associate enterprise less the variable prices incurred within the enterprise.

\section{$G M=T R-A V C$}

Where; $\mathrm{GM}=\mathrm{Gross}$ margin, $\mathrm{TR}=$ Total revenue, $\mathrm{AVC}=$ Average variable costs

However, gross margin analyses do not include fixed or overhead costs such as depreciation, machinery purchases, or permanent labour costs and comparison can be misleading (Firth, 2002). Therefore, estimation of profits for market outlets for unprocessed tea was determined using gross margin (GM) analysis.

GM calculated using the following formula.

$$
G M=\sum P_{y} Y-\sum P_{x} X
$$

Where;

$P y=$ Unit price of unprocessed tea, $P x_{=}$Unit price of inputs used in tea agri-enterprise

$\mathrm{Y}$ and $\mathrm{X}=$ Quantities of output and inputs in kilograms per acre, respectively.

The basis of estimated mean GM by a tea agri-enterprise was on the average tea production per acre produce in a particular day in kilograms and later on, the monthly average gross margin (AGM) was computed accordingly. Mathematical presentation of the AGM equation is below.

$$
A G M=A R-A V C_{(3)}
$$

Where;

$\mathrm{AR}=$ Average revenue of unprocessed tea, $\mathrm{AVC}=$ Average variable cost of inputs used in tea agri-enterprise per acre.

\section{RESULTS AND DISCUSSION}

\subsection{Socioeconomic characteristics}

The gender of the household head had a significance $\left(x^{2}=3.08\right.$, p-value 0.08$)$ relationship with market outlets choice (Table 1). A large proportion of the farmers were males constituting $70.05 \%$ while females were $29.95 \%$. However, among the male farmers $72.69 \%$ choose formal market outlets while $63.73 \%$ chose informal market outlets and among the females, $27.31 \%$ chose formal market outlets while $36.28 \%$ opted for informal market outlets.

\begin{tabular}{|c|c|c|c|c|c|c|c|c|}
\hline \multicolumn{2}{|l|}{ Variable } & \multirow{2}{*}{$\begin{array}{l}\text { Formal } \\
\text { outlets } \\
\text { Freq }\end{array}$} & \multirow{2}{*}{$\begin{array}{l}\text { market } \\
\% \\
\end{array}$} & \multirow{2}{*}{$\begin{array}{l}\begin{array}{l}\text { Informal } \\
\text { outlets }\end{array} \\
\text { Freq } \\
\end{array}$} & \multirow{2}{*}{$\begin{array}{l}\text { market } \\
\% \\
\end{array}$} & \multirow{2}{*}{$\begin{array}{l}\text { Overall } \\
\%\end{array}$} & \multirow[t]{2}{*}{$x^{2}$} & \multirow[t]{2}{*}{ Significance } \\
\hline & & & & & & & & \\
\hline \multirow[t]{2}{*}{ Gender } & Male & 197 & 72.69 & 72 & 63.72 & 70.05 & 3.06 & $0.08 *$ \\
\hline & Female & 74 & 27.31 & 41 & 36.28 & 29.95 & & \\
\hline \multirow{4}{*}{$\begin{array}{l}\text { Marital } \\
\text { status }\end{array}$} & Single & 12 & 4.43 & 1 & 0.18 & 3.39 & 5.8535 & 0.119 \\
\hline & Married & 180 & 66.42 & 68 & 60.18 & 64.58 & & \\
\hline & Divorced & 19 & 7.01 & 10 & 8.85 & 7.55 & & \\
\hline & Others & 60 & 22.14 & 34 & 30.09 & 24.48 & & \\
\hline
\end{tabular}

Table 1. Association of Household Characteristics with alternative Market Outlets

The association between the participation in market outlets verses the size of household and the level of 
education of household head is significant. Household size had a negative relationship ( $t=-2.33, \mathrm{p}$-value 0.01$)$ with the choice of market outlets at 1\% significance level. Formal market outlet had a lower mean household size than that the informal market outlet (Table 2). Household size and composition has adverse impact on the choice of formal market outlet.

Education level of the household heads on the other hand has a positive association $(t=2.53$, p-value 0.01$)$ with the choice of market outlet at $1 \%$ significance level. The mean number of years spent in formal schooling of household heads was 12.73 years and 11.92 years for formal market outlet and informal market outlets respectively. This is an indication that farmers that spent more years in formal schooling chose formal market outlets.

Table 2. Association of Household Characteristics with alternative Market Outlets

\begin{tabular}{|c|c|c|c|c|c|c|c|c|c|}
\hline \multirow[t]{2}{*}{ Variable } & \multirow{2}{*}{$\begin{array}{l}\text { 0verall } \\
\text { N=384 } \\
\text { Mean }\end{array}$} & \multicolumn{3}{|c|}{$\begin{array}{l}\text { Formal market } \\
N=271\end{array}$} & \multicolumn{3}{|c|}{$\begin{array}{l}\text { Informal market } \\
\mathrm{N}=113\end{array}$} & \multirow[t]{2}{*}{$t$-value } & \multirow[t]{2}{*}{$\begin{array}{l}\text { Signifi } \\
\text { cance }\end{array}$} \\
\hline & & Mean & Min & Max & Mean & Min & Max & & \\
\hline Age & $\begin{array}{l}46.28 \\
(11.57)\end{array}$ & $\begin{array}{l}46.10 \\
(11.66)\end{array}$ & 24 & 70 & $\begin{array}{l}46.69 \\
(11.38)\end{array}$ & 23 & 70 & -0.45 & 0.33 \\
\hline $\begin{array}{l}\text { Househol } \\
\text { d size }\end{array}$ & 5.52 & $\begin{array}{l}5.24 \\
(1.77)\end{array}$ & 1 & 12 & 6.17 & 1 & 14 & $-2.33 * * *$ & 0.01 \\
\hline Education & $\begin{array}{l}12.49 \\
(2.87)\end{array}$ & $\begin{array}{l}12.73 \\
(2.66)\end{array}$ & 8 & 19 & $\begin{array}{l}11.92 \\
(3.24)\end{array}$ & 4 & 16 & $2.53 * * *$ & 0.01 \\
\hline
\end{tabular}

Note: Figures in parenthesis represent standard deviation and $* * *=$ significant at $1 \%$ level.

\subsection{Gross margin analysis}

The profitability of unprocessed tea across the market outlets were determined using gross margin analysis. Formal market outlets had the highest average revenue of Kshs 51716.85 while informal market had average of Ksh 45137.65. The average variable costs were Ksh 24531.18 and Ksh 24113.25 for formal market and informal market, respectively. The high deviation in returns is attributable to differences in socio-economics characteristics including the family size and operational costs. Other factors affecting tea returns and the variation in return include efficiency in resources allocation and adoption of production technologies.

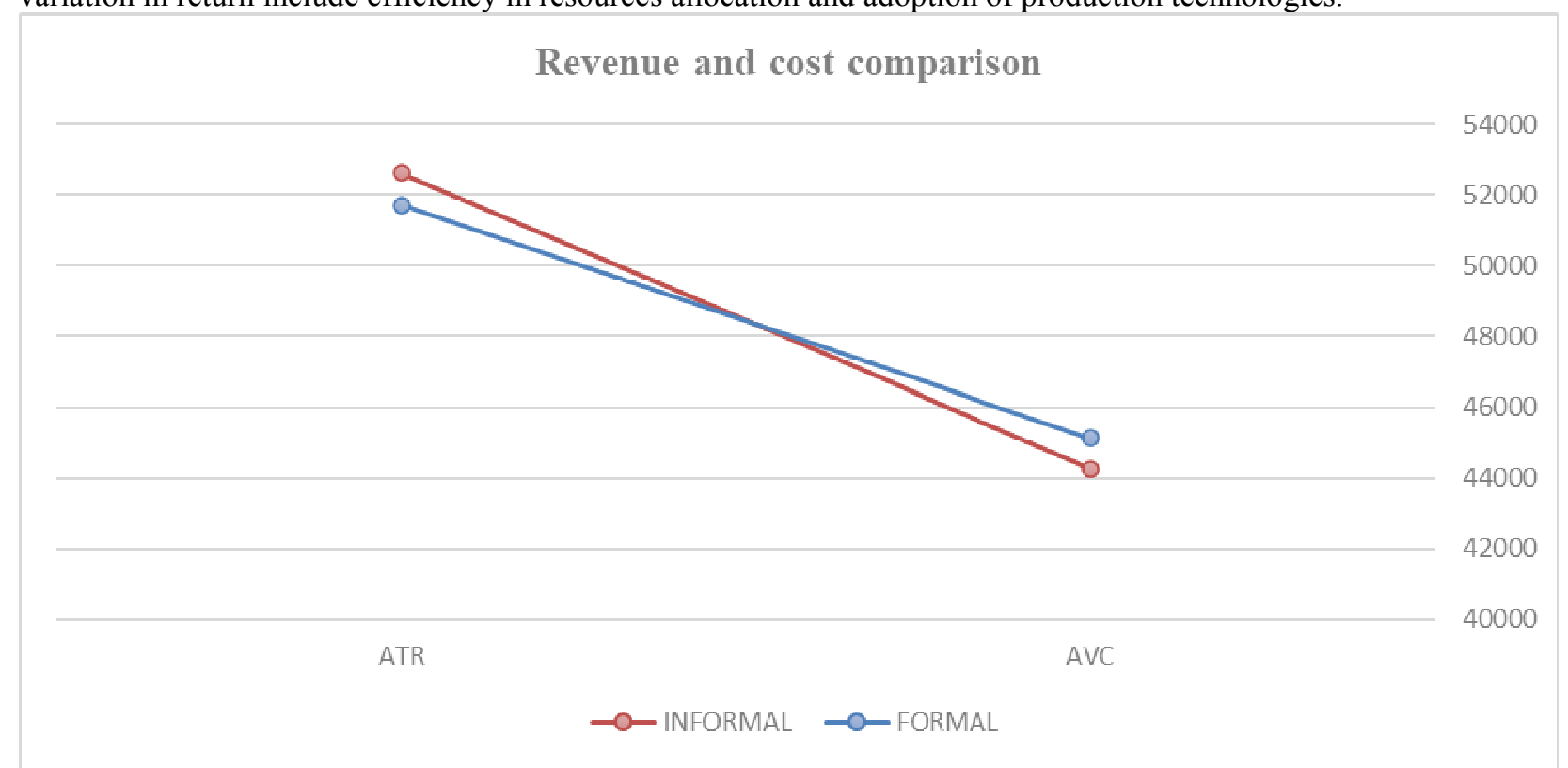

Figure 1. Cost structure of the tea agri-enterprise

The variable costs incurred in marketing of unprocessed tea in the study include labour, transportation, fertilizers, chemicals for weed control and other costs such as pruning, table maintenance and terracing to control rain water flow. Labour and fertilizer costs were major variable costs incurred in tea production for both the market outlets. The costs of fertilizer in formal markets were high with average of Ksh 7176 per acre while labour costs had average of Ksh 5174. Informal market outlets on the hand, fertilizer, and labour were Ksh 5634 and Ksh 4647, respectively (Figure 2). This indicates that farmers in formal market outlets used more fertilizer bags per acre than farmers choosing informal market outlets. They also used more of hired labour, which could be attributed to strict plucking guidelines and standards and increased productivity due to use of fertilizers. 
According to a study to Mwaura and Muku (2007), plucking and fertilizers costs were high among the major operational costs though other households utilized family labour lowering the returns to a household. In addition, labour costs was highly rated by majority of farmers at $96 \%$ and therefore need adequate monthly payment to organize for plucking of unprocessed tea avoid possible losses. (Maina et al., 2015).

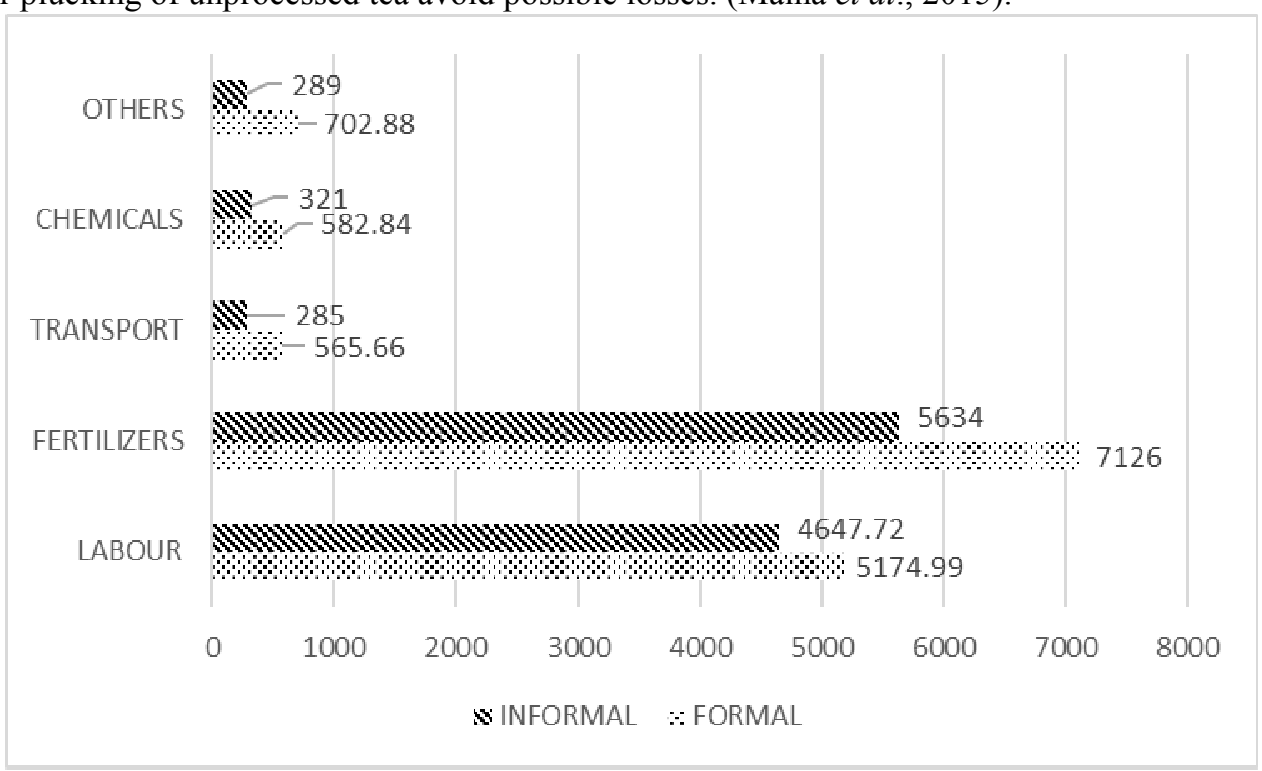

Figure 2. Structure of variable costs

There were costs incurred in tea production and marketing by the farmers although it was not easy to quantify because farmers cannot actually keep proper records. This study therefore relied on the farmer's memory over the last one production period to determine their gross margins in the market outlet choice.

The tea agri-enterprise recorded a positive gross margin rate for both formal markets outlets and informal market outlets (Table 3). Therefore, tea agrienterprises performed differently in terms of profits because its extent in profitability varied between formal and informal market outlets for unprocessed tea. High positive gross margin indicate that farmers selling unprocessed tea to formal market outlets were better placed in tea agrienterprises. This is contrary to a study on economic analysis of milk marketing channels by Ishaq and Abdullah, (2016) found that the level of profit efficiency accrued was higher for informal marketing channels in relation to the formal marketing channels and this is attributed to large amount of milk bought by informal marketing channels.

Tea farmers who sold their unprocessed tea to formal market received a relatively higher prices and gross margin than informal market outlets. Tea farmers obtained a mean price of Ksh 22 per kilogram and a gross margin of Ksh 8.89 per kilogram when sold to formal market outlet (Table 3). The observed difference in returns among these tea farmers was attributed to the variation in prices offered by the marketing outlets. This implies that the higher the prices, the higher the gross margin. Farmers selling to this outlet are therefore encouraged by the prices. They are able to sell to formal market outlet because of higher gross margins and benefits. However, the average price of milk and gross margin for informal market outlets was Ksh 18 per kilogram and Ksh 0.40 respectively. Farmers incur less cost in transport and labour thus the difference in the gross margins. Households may have utilized the available family labour during the production process and therefore lower labour costs as compared to formal market outlet household. 
Table 3. Gross margin analysis

\begin{tabular}{lrr}
\hline Revenues(Kshs) & Formal & Informal \\
\hline Tea yield sales & $2,358.31$ & $1,441.49$ \\
Total Revenue & $51,716.85$ & $24,531.18$ \\
\hline Variable Expenses(Kshs) & & $10,090.44$ \\
\hline Labour & $16,508.20$ & $12,232.00$ \\
Fertilizers & $22,732.00$ & 619.00 \\
Transport & $1,804.00$ & 697.00 \\
Chemicals & $1,859.00$ & 628.00 \\
Others & $2,242.00$ & $24,266.44$ \\
\hline Total variable expenses & $45,145.20$ & 264.74 \\
\hline Gross margin/month & $6,571.65$ & 1.08 \\
\hline Summaries & & 0.01 \\
\hline Gross margin rate (\%) & 12.71 & 0.03 \\
Gross margin/variable expenses (Kshs) & 0.15 & 0.02 \\
Gross margin/labour cost(Ksh) & 0.40 & 0.29 \\
Gross margin/fertilizer cost(Ksh) & 3.64 & 0.43 \\
Gross margin/transport cost(Ksh) & 3.54 & 0.38 \\
Gross margin/chemicals cost(Ksh) & 2.93 & 0.42 \\
Gross margin/others cost(Ksh) & 739.28 & 663.96 \\
Average unprocessed tea produced per acre per month(Kgs) & 19.14 & 16.83 \\
Variable cost of production per Kg of unprocessed tea(Kshs) & 22.00 & 18.00 \\
Average tea selling price (Kshs) & 8.89 & 0.40 \\
Gross margin per kilogram of unprocessed tea (Kgs) & 30.75 & 18.42 \\
Fertilizer cost/kilogram of unprocessed tea(Ksh) & & \\
\hline
\end{tabular}

Formal market outlets show total average revenue of Ksh 51716.85 while informal market outlets had an average revenue of Kshs 24531.18. This indication shows the extent of profitability for market outlets. Formal market outlets offer higher price relative to informal and could be the reason for difference in revenues. In addition, the yield of unprocessed tea might be crucial in determining the overall revenues because more yield increases the returns from individual market outlets. Kadigi (2013) analyzed and compare the profitability milk marketing channels and found contrary to this study because informal milk chain actors in both areas received large profit than their counterparts in the formal milk market channel. The difference in milk price attributes to observed difference in milk returns among actors selling milk in informal and formal milk chain.

On average, tea farmers were able to sell 739.28 kilograms and 663.96 kilograms of unprocessed tea per acre to formal market outlets and informal market outlet, respectively. This could be attributed to higher monthly price and accessed to credit facilities because farmers are able to source for inputs and pay for recurrent variable costs with ease. Continuous trainings and shared knowledge through farmer's field school attributes to higher yield for farmers selling to formal outlets (Kagira et al., 2012; Waweru, 2012).

\section{CONCLUSION AND POLICY RECOMMENDATIONS}

Tea agri-enterprises use different market outlets to sell their unprocessed tea although amount of unprocessed tea and reasons for delivering through each market outlet differs. According to this study three main market outlets (KTDA, private companies and agripreneurs) that tea agrienterprises utilize in Chesumei Sub-County, Nandi County were identified from the survey result. Tea agri-enterprises can choose to sell all or proportion of their unprocessed tea through any one of these market outlets. The formal market outlets have higher gross margins than informal market outlets for unprocessed tea. This indicates the need to encourage farmers to supply to formal market outlets in order to maximize profits and thus improving the household wellbeing. Therefore the study recommends that policies should allow KTDA, private companies and other key stakeholders through the County Government to further reduce the prices of fertilizers to increase the gross margins for farmers.

\section{REFERENCES}

African Development Bank (AFDB). (2013). Annual Report. Tunis.

Becker, K. F. (2004). Fact finding study: The informal economy. Stockholm, Report for Sida.

International Labour Conference, and International Labour Office (Eds.). (2014). Transitioning from the informal to the formal economy: Fifth item on the agenda.

Ishaq. M.N., and Abdullah. m. (2016). Economic analysis of milk marketing channels in SouthRegion of Punjab, Pakistan: An empirical estimation of marketing and profit efficiency. https://www.researchgate.net/publication/299403800

Joshi,A(2004). Farm Household Income, Investment, and Consumption. Economic and Weekly, 39(4), 321-323. 
Kadigi, L.M. (2013). Factors influencing choice of milk outlets among smallholder dairy farmers in Iringa Municipality and Tanga. Masters Thesis, Sokoine University of Agriculture, Tanzania.

Kagira, K. E., Kimani, S.W., and Githii, K. S. (2012). Sustainable Methods of Addressing Challenges Facing Small Holder Tea Sector in Kenya: A Supply Chain Management Approach. Journal of Management and Sustainability, 2(2), 75-89.

Karimi, W. R. (2008). Factors affecting market output of small scale suppliers of Kenya Tea Development Agency: A case of suppliers of Kathangariri factory. Masters Thesis, Kenyatta University, Kenya.

Keraro,V., Mokamba, J., Cheluget, J., Kithitu, J., and Mbogo, P. (2012). Strategies for enhancing effective management of tea factories in a liberalized smallholder tea subsector in Kenya. Prime Journal of Business Administration and Management, 2(11), 736-745.

Kenya EconomicReport, (2013). Creating an Enabling Environment for Stimulating Investment for Competitive and Sustainable Counties. Nairobi: KIPRRA.

Kirui, J., Kiprono, R. J, and Tirop, C. H . (2014). Socio-Economic Effects of Liberalization of Small Scale Tea. Research Journal of Finance and Accounting, 5(24), 148-162.

Kiprono, P. K., Sudoi, V. K., Kaburu, M., and Mwaura, F. K. (2011). The socio economic factors influencing productivity of the smallholder subsector of the kenyan tea industry: A survey of nandi district. International Journal of Current Research, 3(10), 31-34.

KNBS, (2016). Micro, Small and Medium Establishment (MSME) Survey: Basic Report. Retrieved from Kenya Bureau of Statistics website: http://www.knbs.or.ke/downloads.

McElwee, G. (2006). Farmers as entrepreneurs: Developing competitive skills. Journal of Developmental Entrepreneurship, 11(3), 187-206.

Mwaura, F., and Muku, O. (2007). Tea Farming Enterprise Contribution to Smallholders' Well Being In Kenya. AAAE Conference Proceedings. Tea Research Foundation of Kenya.

Maina. F.N.W., Mathenge. P.W., Mwathe. Z.M., and Mathenge. M.M. (2015). Challenges facing the tea Sector in Nyeri County. Proceedings of the First International Conference on Tea Science and Development.

Mwaura, F., Muku, O., and Nyabundi, W. K. (2010). Using research findings to formulate extension tools that incorporate stakeholders' aspirations: The case of tea farming in poverty reduction strategies among smallholders in Kenya. Outlook on Agriculture, 39(3), 217-222.

Obare, M. J. (2015). The impact of informal economy on employment creation: The case of kamukunji jua kali. International Journal of Economics, Commerce and Management, 3(6), 853-888.

Pardi, S., and Zainu, I. (2014). The Effect of Market Orientation and Entrepreneurial Orientation toward Learning Orientation, Innovation, Competitive Advantages and Marketing Performance. European Journal of Business and Management, 6(21), 69-81

Yusuff, O. S. (2011). A Theoretical Analysis of the Concept of Informal Economy and Informality in Developing Countries. European Journal of Social Sciences, 20(4), 624-636. 